\title{
Black Hair Everywhere!
}

\author{
Kaifa Roland L* \\ University of Colorado at Boulder, Colorado, USA \\ *Corresponding author: L Kaifa Roland, University of Colorado at Boulder, Colorado, USA
}

Received: 眥 February 07, 2020

Published: 踾 February 18, 2020

These days, Black girl hair is all over the place (pun intended)! Certainly, the styles donned by women in the black world spans from short naturals, to cornrows, braided extensions, perms, weaves, dreadlocks, and what I call "funky flowing 'fros." I should know, as I've worn my type 4-c hair in each of these styles at various points in the past decade. But black girl hair has also highly visible in popular culture in the past few years-perhaps this is the Michelle Obama effect? For an academic, I consider myself something of a television aficionado (I call myself that to avoid the label of nighttime "couch potato"). Some of my favorite shows over the last few years were Scandal (ABC), How to Get Away with Murder (ABC), and Being Mary Jane (BET). Yes, they are outrageous and dramatic and fictional, but they feature powerful black women as lead characters and-given that I have long contemplated an ethnographic project is on black women's hair practices in Cuba-I cannot get enough of what is being done with their hair!

\section{Black Hair Goes Primetime}

On Scandal, Kerry Washington starred as Olivia Pope. She is a political "fixer" who-in the early seasons of the show-happened to be having an affair with the President of the United States. Usually her hair is worn in a weave that is flat-ironed and parted on the side (she wears bangs in scenes that flash back to the president's campaign trail), but every now and then her hair curls up somewhat when she is near water (in the shower with the President on one occasion, and at the beach with her sexy spy boyfriend when they had escaped briefly "to the sun"). While fans (called "gladiators") see Olivia in bed on quite a few occasions, we seldom see her do anything special to her hair at bedtime besides wearing it back in a bun. Further, when Pope was kidnapped (Season 4, Episode10/Run), her hair fluffed out quite a bit and she looked rather disheveled, but viewers were given the impression that this was largely because she was unable to sufficiently groom herself, not because her blackgirl hair texture required any special maintenance.

Gabrielle Union starred on Being Mary Jane as a highly visible anchorwoman on a cable news network who makes terrible decisions in her personal life. Like Olivia Pope, Mary Jane Paul (aka Paulette) also wears her hair in a varyingly styled weave. This was made evident on the episode "Let's Go Crazy" (Season 2, Episode 7) when she took her weave out in anticipation of a hair appointment the following morning. When her weavologist explained that she forgot to call to cancel the appointment, black women everywhere understood the panic that went through Mary Jane when she realized she would have to go on air with the big bushy 'fro she was rocking at the time. She explained her beauty insecurity as her niece saved the day by bringing a suitcase of hair weaving equipment for the late-night hair session.

Do you know why I begged you to come over here? Because your perfect aunt was terrified of going to work without her weave. Terrified that no one would think I was beautiful...that people would think I was average and I'd be invisible. So maybe that pedestal you put me on is a little too high. I'm human. (BMJ S2, E7, final 3 minutes)

This is scene powerful because it illustrates the power a black women's hair can play in her self-perception. A character who had always come across as confident and beautiful reveals the kinds of insecurities that can be masked by the right hairstyle. Beyond the weave emergency, though the audience regularly witnessed Mary Jane wrapping her hair up for bedtime or sleeping and showering in a bonnet. Black women audience members know that-aside from very few exceptions-a black woman does not just get in the bed, the shower, or the pool without some kind of consideration for her hair, and Being Mary Jane acknowledges that fact.

My latest addiction, How to Get Away with Murder, came on immediately after Scandal while the latter was still on the air and is produced by the same black female powerhouse, Shonda Rhimes. The show stars Emmy, Tony, and Academy Award winner Viola Davis. Annalise (formerly Anna Mae) Keating is a tenured law professor and an ethically questionable defense attorney. There is a lot more that could be said about Professor Keating, but in terms of hair, she has a penchant for wigs during the day, but early in the series (Season 1, Episode 4/Let's Get Scooping), the audience 
witnessed her dramatically shed her wig and makeup as she cried at the discovery that her husband had had an affair with a dead girl for whom she was defending the accused. As in BMJ, this was a powerful scene because of the way it challenged viewers to observe a woman unmasking those trappings of beauty in a way seldom confronted so directly on screen. Following Mary Jane's explanation, the wigs appear to symbolize security and confidence, as Annalise regularly appears without them. For example, she was wig-less when she went on an alcoholic bender during the winter holidays of that first season (Season 1, Episode 11/Best Christmas Ever) after setting up her sexy police officer boyfriend for the murder of her husband though she knows he did not do it; at another point, her wig was cocked to the side when said sexy boyfriend had her pressed up against the wall in a sexual embrace (Season 1, Episode 9/Kill Me, Kill Me, Kill Me)! When she returned to her home after the holidays, she acknowledged that she needed help by calling her "V.I.P." mother played by Cicely Tyson (Season 1, Episode 13/Mama's Here Now). She is wig-less throughout the episode, but-as occurred in Being Mary Jane-real talk happens between this estranged mother and daughter while doing hair. Though the comb was all wrong, and "the kitchen" which had been mentioned was not addressed ${ }^{1}$, I sat with my mouth agape as I watched a black woman's natural hair (coarsely textured like mine!) being combed on primetime network television. Historically, thick, coarse, "nappy" hair in its natural state has been the epitome of unacceptability, and the definition of "not presentable." It had to be covered or straightened or even cut off; it could certainly never displayed in a close-up on television. Shonda Rhimes and Viola Davis validated the existence-if not the beauty-of the full array of black women's hair textures in that one scene.

I provide this lengthy lead-in to think about what it means to "do" black women's hair. The television characters I describe above are characterized as women of above-average means in the United States, and each of them reveals varying degrees of the processes involved in making oneself presentable to the broader (white/male) world: Olivia Pope's straight hair is rarely out of place, she always fits in perfectly in the white world, though there is the slightest evidence of an Africanoid curl when there is water involved; likewise, Mary Jane is always well-coiffed in the daytime, but this show (on the Black Entertainment Network whose first three seasons were produced by Mara Brock Akil of Girlfriends and The Game fame) foregrounds the main character's many black woman realities after hours; finally, Annalise/Anna Mae Keating, like Mary Jane Paul/ette has a more severely split personality. By day, she has it all together as a professor in a predominately white world (can I get a witness?), but by night her mask/wig is allowed to come off and the insecurity and baggage from her youth haunts her. She finds the information she needs to (hopefully!) begin healing sitting on the floor between the knees of her mother while getting her hair done.

\section{A World of Black Hair: Spotlight II}

As black American women, many of us believe we are the only ones with these hair issues. This despite the fact the the Dominican and Brazilian blow out are styling techniques used on white women and women of color throughout urban areas in the United States. There are black women with varying grades of Africanoid hair throughout the Americas who do not have access to the same booming black hair industry as those of us in the United States. I am particularly interested in how the millions of women of African descent in one corner of the world that has long been cut off from the United States get their hair needs met: Cuba.

When I first conducted research in Cuba, a young (black) man I was interviewing in Santiago-de-Cuba brought me to meet his family. As we were passing through the complex of neighboring apartment units in his solar, I observed a woman using a straightening comb to do another woman's hair, while others waited. The scene was familiar to me, but I did not delve further into the topic at the time. Perhaps it was "too normal" in my mind to be worthy of deeper investigation. On another occasion, when I had just begun to think about black women's hair as a topic of study, I observed a white woman with her brown-skinned, coarsehaired daughter (racialized as javada in Cuban terminology) on the porch of their home in Pinar del Rio. Sitting on the patio next door from the guest house where I was residing, I heard the mother muttering aloud about how difficult "this child's hair is to do." As the little girl's fine haired, white-skinned sister skipped about the porch during the ordeal, I wondered what kind of esteem the young brown girl would have when she grew up in Cuba's whiteaspiring society. Similarly, as I walked about Havana with my fluffy 'fro flowing, I was greeted by offers from what felt like every other black woman I passed to "do" my hair; my big 4-c afro was clearly viewed as problematic by my distant kinswomen. Fortunately, my hair provided an opportunity to visit an in-home salon myself to get braided extensions.

\section{Fieldnotes from a Havana Home Hair Salon}

Yesterday I was approached by a 50-ish year old man whom I had met on previous visits who wanted to introduce me to his daughter who braids hair. Since I had just washed my hair the day before, I went and made an appointment for the following morning. There were three youngish women (20-something) waiting in chairs in the sunlit entryway to the small house to have weaves put in, and one older woman (over 50) in the chair getting multicolored cornrows put in her naturally gray hair. I told the stylist I was interested in getting cornrows like the woman whose hair she was doing but using all black hair.

I returned the next morning (Sunday) at the appointed time. Another woman was already in the seat with the early stages of small cornrows (corridos de trensas) needed to begin a weave.

${ }^{1}$ For readers who are unfamiliar, "the kitchen" is a euphemism used in the black community to describe the most tightly coiled hair at the nape of the neck. 
After the stylist-Reglita-explained to me that there wasn't enough of the black hair color I wanted (because it was desaparecido ${ }^{2}$ ) but she could blend the reddish/brown color she had with the darker color I wanted, the woman in the seat was asked if she would mind if I went first since mine would only take about half an hour ${ }^{3}$. She distributed the reddish color across the other lady's fingers, and gave me a handful of the dark color to hold.

There was a Steven Segal movie on TV with Spanish subtitles and the volume down low. It was rarely the focus of attention. While getting my hair done, there were several interruptions, some of which annoyed Reglita. First the husband of the woman getting her hair done stood outside and the woman went out briefly to wish him a good day. Very soon after, a man (older and black) came by whom Reglita seemed to know. He asked how much it cost to get hair done like mine; she tried to avoid answering in front of me but he kept asking. She told him \$15 CUC; incredulous, he asked "en fula?" shaking his head, while she confirmed the hard currency price. Fifteen CUC (the equivalent of US\$15) was the price I had been quoted the day before though I was certain Cubans paid far less, likely in the far less valuable national currency prices (i.e., Moneda Nacional/MN). The man asked for and was permitted to get some water. A white male neighbor from across the courtyard called out to her to tell her about some cheese. She said she was braiding and would talk to him later. An older woman dressed in white ${ }^{4}$ was passing by and the woman waiting to get her hair done jumped up and greeted her with kisses and they chatted for a while. Though the visitor greeted the stylist and me briefly, it was apparently not sufficient for Reglita's taste: after the older woman had left, Reglita asked the weave woman if she knew the lady in white, to which she curtly responded, "no," which I thought was odd since they had just greeted and chatted like old friends. Reglita grumbled about how the woman had not asked permission to enter as is normally expected. Soon after, a tall man with long dreadlocks stood in the foyer and she offered him water. He politely begged our permiso (pardon) and wiped his feet before entering. A blond woman I assumed to be the wife of the white man who had passed by earlier came in soon after to show Reglita the block of cheese her husband had mentioned. She told her how much it cost and how much she had bought. There seemed to be the promise of a transaction.

Eventually, Reglita's mother came down the spiral staircase toward the back of the room where my hair was being styled (I had barely noticed the staircase before she came down, but I had wondered where the rest of the household was). I had met her mother the day before; she was a big woman with a big personality. She greeted everyone, but I cannot remember what she talked about; I do recall that she turned on the fan and we had to secure the weave that was going to be "implanted" in the waiting woman's hair. I also recall that at one point the woman waiting for her weave (denoted in my fieldnotes as WWW) picked up the hair that was sewn to a strand and wrapped in newspaper and cuddled it to her face, saying "oh my god, I love it, I love it, I love it!" I recoiled a bit at the unbridled adoration of finely textured hair by this woman whom Cubans would catergorize as a javada. As described of the child I observed in Pinar del Rio, a javada a person whose light complexion suggests European heritage while their coarse hair texture reveals African ancestry. While other mulatas and mulatos may have darker or lighter complexions that reveal racial mixture, their fine hair texture is perceived as more desirable in Cuba's white aspiring society. Therefore, the straight black hair that was about to be sewn into her head would adelantarle or advance her status.

Between all of these comings and goings WWW and I figured out that we knew one another. She was the pregnant housekeeper at [a nearby hotel] when I dropped by in May. Her child is now 2 months old. Before our discovery, I heard her grumbling about diapers. At another point, she was talking about watching the Mexican telenovela the night before and seeing a scene where there were several hairstyle options, and going crazy for them. At one point I asked Reglita if the weave we were holding down with the remote control was synthetic and was told it was natural. The night before, [a mutual friend] had told me that she had grown her (mulata) hair out and cut it to sell to Reglita for $\$ 100$ CUC. She had grown it back and cut it again in February for $\$ 50$ CUC. She is now in the regrowing stage again, with her hair currently at shoulder length. WWW said she lived in Playa near Marina Hemingway (which is rather far), I told Reglita she must be good if WWW came that far just to get her hair done. I was told WWW's weave would take around two hours, which didn't seem like long for what I've heard about how long weaves take in the US.

As I stated at the beginning, black girl hair is everywhere. In a 2009 film entitled "Good Hair," comedian Chris Rock produced a documentary that portrayed the globality of the black hair industry. The film was problematic in many ways, but-like the television shows described at the beginning of this paper-it put the question of black women's hair practices on a screen for the world to see. Like Annalise Keating or Mary Jane Paul, it isn't that black women do not realize our own hair issues; it is just that those issues are normally kept "between us sisters." It is uncomfortable for us to take our wigs and weaves off in front of those who do not know our reality. My objective in my study of black women's hair practices in Cuba is to expand the circle of sisterhood to a place long outside of U.S. consideration. What are their experiences? How parallel or different are they from black women's experiences elsewhere in the African diaspora? And does the home hair industry provide a space for black women's economic independence in Cuba's rapidly changing society?

${ }^{2}$ Translates as "disappeared," meaning it was no longer available through her informal networks.

${ }^{3}$ Indeed, the entire visit lasted approximately 40 minutes.

${ }^{4}$ I did not get the sense that the woman was an iyawo initiate in the African-based religion of Santeria of which many Cubans of clear African descent are practitioners; such individuals must ritually dress in white for one year. I wondered instead if the woman was a child of Obatala-an orisha (or deity) in Santeria whose identifying color is white, or perhaps a steward in a more mainstream Christian church). 
(C) This work is licensed under Creative To Submit Your Article Click Here: $\quad$ Submit Article DOI: $10.32474 / J A A S .2020 .01 .000118$

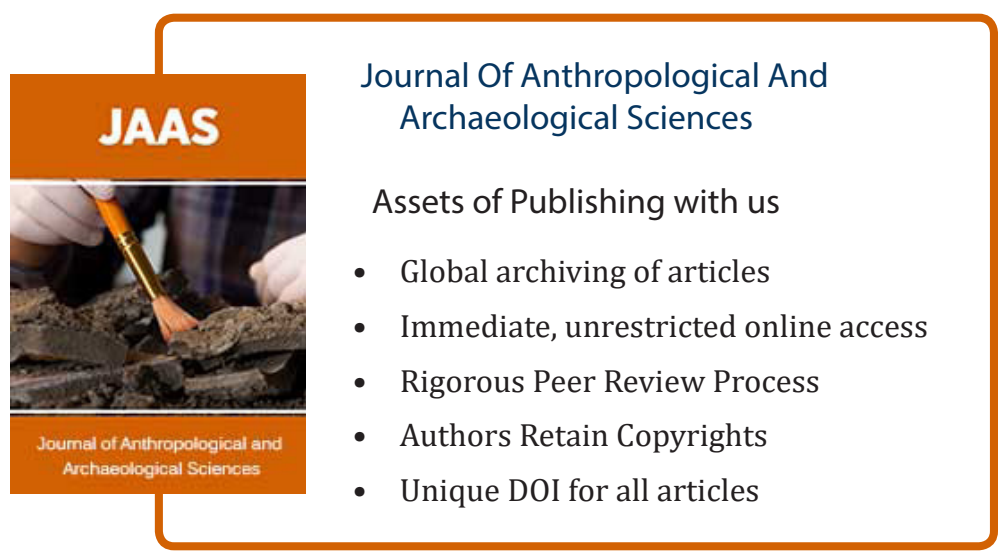

